\title{
Pediatric Epilepsy
}

\author{
David G. McLone, Editor-in-Chief
}

Surgical management of epilepsy in children has seen a rapid and recent development.

With the awareness of the deleterious impact of recurrent seizures on the immature brain, came a more aggressive attempt to control seizure earlier in the child's life. An additional benefit is the ability of the developing brain to repair itself. It is obvious to most that the child's nervous system has significant differences from the adult. It is therefore not surprising that the site of the seizure and the outcome after surgery would be different from adults.

Warwick Peacock has put together a series of articles on pediatric epilepsy. This is a very welcome series, and we appreciate the effort put forth by Warwick and the other authors. This series will be presented over the next several months under 'Perspectives in Pediatric Neurosurgery'.

\begin{tabular}{ll}
\hline KARGER & ( ) 2001 S. Karger AG, Basel \\
Fax +4161306 12 34 & \\
$\begin{array}{l}\text { E-Mail karger@karger.ch } \\
\text { www.karger.com }\end{array}$ & $\begin{array}{l}\text { Accessible online at: } \\
\text { www.karger.com/journals/pne }\end{array}$
\end{tabular}

